\title{
Optimizing Learning Management System to Teach English Grammar
}

\author{
Isnaini Nur Safitri \\ isnaini_ns@polinema.ac.id \\ Politeknik Negeri Malang \\ Pritantina Yuni Lestari \\ pritantinayl@polinema.ac.id \\ Politeknik Negeri Malang
}

\begin{abstract}
This study aimed to investigate the use of the Learning Management System (LMS) to teach English Grammar subject in online learning during covid-19 outbreak. This study was descriptive qualitative research with second semester students as the subjects of the study. They were students from English department taking Structure 2 as the compulsory subject. The data were collected by conducting a survey to 71 students who were purposely selected to know the optimization of using LMS in teaching English Grammar during the covid -19 outbreak. Questionnaire was used to do a survey. The results show that the materials uploaded in the LMS are useful to help students understand about English Grammar, especially for the topic taught in the second semester. Furthermore, the use of quiz features in LMS can motivate them to learn since they can know the results and the correct answer directly from the LMS. It also can increase the students' confidence when doing the same test. However, it was found that the use of LMS cannot replace the direct explanation method from the teacher which is still stated as an effective way in teaching English Grammar subjects.
\end{abstract}

Keywords: LMS, Teaching, English Grammar

\section{Introduction}

Pandemic of Corona Virus Disease or Covid-19 have affected the whole aspects in life. One of most influenced is education system. Since there is social distancing issued by the government, all schools and campus are not allowed to conduct offline face-to-face of a teaching and learning process. This is based on notice from Ministry of Education number 36962/MPK.A/HK/2020 stating that to 
prevent the spread of Corona Virus Disease and to protect employees, students of university, students, teachers and lecturers, all activities should be done from home (Makarim, 2020). Moreover, tasks are done from home and students are asked to study from home as well. Any meetings are managed using video conference and the government said there will be facilities to support it. Therefore, the teaching and learning process should also be done online.

The shift from the study in the classroom to study from home brings consequences. The use of information technology during covid-19 outbreak might increase the quality of teaching and learning process itself. In addition, it might assist a collaborative learning circumstance, provide more chances for students to have practice and access to learning materials, and make the teaching and learning process effective and efficient (Chugh, 2010). Moreover, Alizadeh (2019) stated that information technology offers the students with numerous applications and systems in virtual learning environment. On the contrary, teachers need to be creative to find suitable teaching method and to choose an appropriate platform in conducting the online teaching and learning process, particularly in teaching language. Stable internet connection is also matters for it.

There are many available platforms that can be used by teachers. One of them that is widely used is Learning Management System (LMS) (Alvares et al. cited in Basal, 2016). According to Osmani, et.al (2016), LMS is a software application allowing the teachers to design online learning. In short teachers are able to create, manage, and deliver e-learning, and assign students to have interaction and learning in an interactive environment. By using LMS, teachers are able to upload the materials and give activities using features in LMS. LMS also 
offers many educational gains for the students and the teacher especially to improve their learning engagement and upgrade the interaction with the teacher (Alizadeh, 2019). Sayfouri cited in Alizedeh (2019) mentioned that LMS assists both teachers and students by eliminating time and space and provides them with teamwork and information exchange. Furthermore, it allows them to present various online resources and tools (Motteram cited in Alizadeh, 2019).

Organizing online teaching and learning process using LMS is quite challenging, especially in teaching grammar during covid-19 outbreak. Teachers have to prepare activities that provide students with various tasks and that allow them to practice using English grammar. It is in line with Chugh (2010) who stated that implementing online learning should be well-designed based on the situation and condition. Besides, a swift in conducting the teaching online in the middle of the semester made the teachers need to adapt the syllabus as well. They have to find and prepare the materials that assist the students to study by themselves. They also need to find the appropriate media for teaching grammar.

Nevertheless, there has been researches done on the use of LMS in language teaching. Rymanova et al (2015) who conducted a research on the LMS Moodle for English Language Teaching revealed that most teachers agreed that using LMS Moodle is appropriate for teaching English and constructively gain students in the learning process. A research also performed by Cakrawati (2017) entitled "Students' Perception on the Use of Online Learning Platforms in EFL Classroom" found that students gave positive response concerning the use of Edmodo and Quipper as online platforms and it could save time and effort in learning as well as improve their comprehension about the lesson given. Additionally, a research on 
the EFL learners' perception of using LMS done by Scrichanyachon (2014) disclosed that LMS is a useful tool supporting the English learning, but traditional learning is more useful; and the students' perceived in the moderate level.

Teaching grammar means equipping students to utilize the linguistic forms accurately, meaningfully, and appropriately (Larsen \& Freeman, 2001). In another words, students should be taught the rules of language or sentence pattern, meaning and use (Widodo, 2006). Thus, since the use of video conference has not been familiar enough for online teaching, the issue of students' internet credit, and the students' internet connection, the researchers decided to use LMS to teach English Grammar. In short, the aim of this study was to look over the optimization of LMS in teaching grammar during covid-19 outbreak. It focuses on the students' believe on the advantages of using LMS i.e. NEO LMS and Moodle in learning English grammar, the use of quiz feature to provide practices, and their perception of using LMS comparing to offline learning.

Using LMS to teach English Grammar has been commonly used. Bikowski (2018) explained that using technology to teach grammar can be the most effective way integrated to the curriculum and lesson. To facilitate it, students need to be given appropriate activities or tasks. Larsen and Freeman (2001) clarified that activities in teaching grammar can be done inductively and or deductively. Inductive tasks are implemented by giving some examples (it can be the form of texts, dialogues, or sets of examples with context) and the students figure the rules they are going to learn. In contrast, deductive tasks are applied by giving the rules directly and asking students to do the exercises. 
Pumjarean et al (2017) implemented a research on Moddle LMS for EFL Grammatical and Writing instruction. It was found that Using Moodle's LMS can significally improve the knowledge of English grammar and paragraph writing skills. Another research done by Khan et al. (2018) concerning the effectiveness of an Educational Software System in teaching English grammar and it used deductive approach in teaching grammar. The results indicates that the system significantly affects students' achievement better and increase students' interest to reach their target. Al-Essa (2018) did a research as well on the impact of using Edmodo to promote students' English grammar. She discovered that EFL students have positive attitude on the use of technology and their motivation to learn English was boosted.

\section{Research Method}

This study employed a qualitative approach. It is a method in which someone tries to explore people's life histories or everyday behavior using interpretation to analyze the data (Silverman, David \& Marvasti, Amir, 2018). In this study, the researchers investigated the use of LMS to teach English Grammar. In short, it is suitable for implementing this approach in this study.

This study was conducted two months from March until May 2020. It involved 71 respondents derived from three classes. They were the students of Diploma three and four of English Department Politeknik Negeri Malang taking English Grammar 2 (Structure 2) as the compulsory subject. They were in the second semester of their study. They were selected by the use of purposive sampling meaning that the respondents were chosen based on the need of the study. 
Instrument used to collect the data was questionnaire. The questionnaire was used as the representative questions addressed in interview since it cannot be conducted during covid-19. Besides, it allows the researchers to have inferences from wider population (Silverman, David \& Marvasti, Amir, 2018). It involved 19 questions addressed to the students. It was distributed at the end of the teaching and learning process. It consisted of open and close questions to know the benefits of use for LMS in learning grammar, to get the information on the use of quiz features in LMS, and to know their perception on whether they prefer having face-to-face offline learning or online learning. The results were in the form of qualitative data. The data then were analyzed descriptively and qualitatively. The researchers then interpreted them by crossing and checking the responses of the students in the questionnaire. Key features related to the use of LMS in the teaching and learning process were noted and reappearing of particular opinion was assumed as the respondents' concern.

\section{Result and Discussion}

There were 19 questions wrapped up in a questionnaire used to measure the use of LMS in teaching Structure 2. The questions were divided to 2 big parts, namely (1) the use of LMS in helping the students understand the materials and (2) the use of quiz feature in LMS.

The first part of the result shows that the materials uploaded in the LMS are useful to help students understand about English Grammar, especially for the topic taught in the second semester. 


\section{The use of LMS is really beneficial to study the lesson}

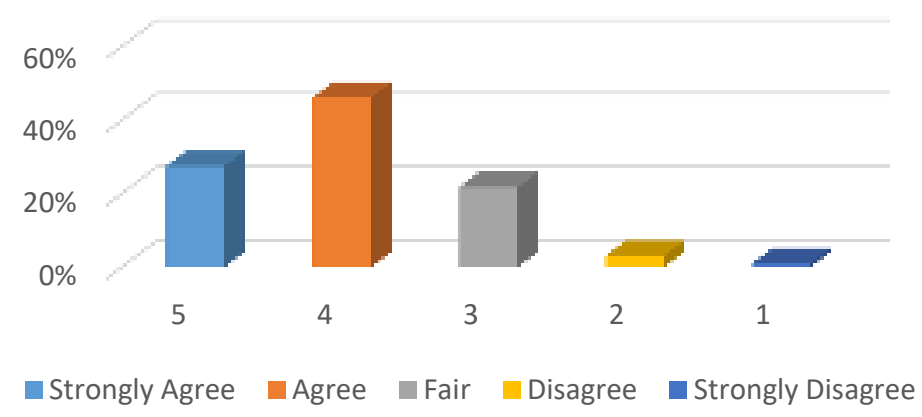

Figure 1. The Use of LMS to Study the Lesson

Figure 1 shows that $27 \%$ of the students is strongly agree that the use of LMS is really beneficial to study the lesson, while $46 \%$ of the students is agree. The other $22 \%$ of the students states that the use of LMS may be beneficial to study the lesson, while the $3 \%$ of the students is disagree, and the rest $1 \%$ of the students is strongly disagree that LMS is useful to help them study the lesson. It can be seen that most of the students agree with the statement stating about the benefit of LMS to study the grammar lesson.

The use of LMS can help them to study the lesson. They enjoy using LMS in studying Structure 2 lesson. The module, PPT file, and video uploaded in LMS can also solve their problem in doing the assignment from the lecturer. This is in line with the research done by Alizadeh. Alizadeh (2019) stated that LMS brings many educational gains for the students and the teacher especially to improve their learning engagement and upgrade the interaction with the teacher. Besides, Pumjarean, et al. (2017) also mentioned that implementing Moodle's LMS can significantly improve the knowledge of English grammar and paragraph writing skills. Thus, it can be concluded that the use of LMS can be beneficial to the 
students in studying the material especially in the pandemic situation which obligates everyone to do everything at home.

The next question is about the use of quiz features in LMS. The following figure serves the result based on the answer of the students.

\section{The Use of Quiz Feature in LMS}

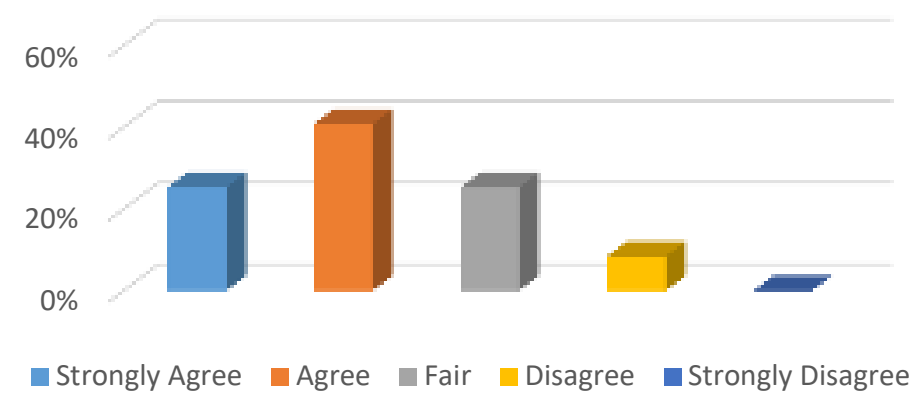

Figure 2. The Use of Quiz Feature in LMS

Figure 2 shows that $25 \%$ of the students stated strongly agree that the quiz is helpful, $41 \%$ of the students stated agree that the quiz is helpful, $25 \%$ of the students stated fair about the use of quiz in LMS, and the rest $8 \%$ of the students stated the quiz feature is not useful. Furthermore, the use of quiz features in LMS can motivate them to learn since they can know the results and the correct answer directly from the LMS. It also can increase the students' confidence when doing the same test.

The students stated that the benefits of quiz feature in LMS is about how they can know the answer directly after submitting the quiz. It will make them satisfied if the answer is true and stay motivated to study harder. This result is supported by Gamage et al. (2019) who clarified that the multimodal quizzes are effective in teaching and assessing a theoretical engineering course and provided efficient methods to replace conventional assessments. The FI and DI indexes are useful statistical tools in redesigning appropriate sets of questions. Time-poor 
academics will benefit from using these easily attainable Moodle statistics to inform decisions while revising the quizzes and making assessments more autonomous.

However, it was found that the use of LMS cannot replace the direct explanation method from the teacher which is still stated as an effective way in teaching English Grammar subjects. It is in accordance with Srichanyachon (2014) that LMS is a useful tool supporting the English learning, but traditional learning is more useful. Besides all of the benefits of LMS and its features, the students still find difficulties related to the internet connection and time management. They prefer to study in the classroom because they are able to keep in touch with the other students and the lecturer. The students are able to have discussion with their friends, directly ask the lecturer related to the materials and assignment. The students prefer having direct explanation from the teacher to indirect explanation because they think that it makes them easy to understand the materials. They will never have the internet connection problem when they study in the class. It is in line with the result of the research done by Rymanova et al (2015) that the use of Moodle for ELT can effectively engage students in learning, but it effects the teachers to have extra work preparing the online teaching and learning. In short, beside the students, the teachers

also have to do some additional work when using LMS to teach. They have to prepare the materials, tasks, exercises, and also the proper evaluation ways for the students.

\section{Conclusion}

The findings of the study revealed that the students agree if LMS is beneficial for them. They can easily download the file given by the lecturer to help 
them study. The materials upload in the LMS can also help them in doing the exercises from the lectures.

Moreover, the quiz feature in LMS can help the students directly know the correct answer of the question given, so it can increase their motivation to study harder in order to be able to choose the correct answer. It also boosts students' confidence when doing the test since they can directly know whether their answer is correct or not. Besides all of the benefits, the students still prefer to study in the real classroom because they will be able to have direct interaction with their friends and also lecturer.

\section{References}

Al-Essa, N. S. (2018). The Impact of Using Edmodo as a Blended Learning Medium on Promoting Saudi EFL Female Secondary School Students' English Grammar. Arab World English Journal.

Alizadeh, Iman. (2019). Using an LMS in Teaching English: A Qualitative Content Analysis of Medical Sciences Students' Evaluations and Suggestions. The Qualitative Report, 2019, 24(11), 8, 2851-2873. https://nsuworks.nova.edu/tqr/vol24/iss11/12

Basal, A. (2016). Extending the functionality of LMS for English language teaching. In Conference proceedings. ICT for language learning (p. 142). libreriauniversitaria. it Edizioni.

Bikowski, D. (2018). Technology for teaching grammar. The TESOL Encyclopedia of English Language Teaching, 1-7.

Cakrawati, L. M. (2017). Students'perceptions on The Use of Online Learning Platforms in EFL Classroom. ELT Tech: Journal of English Language Teaching and Technology, 1(1), 22-30.

Chugh, R 2010, 'E-learning tools and their impact on pedagogy'. In Ubha, DS \& Kaur J (eds), Emerging Paradigms in Commerce and Management 
Education. GSSDGS Khalsa College Press, pp. 58-81, ISBN: 978-81909755-2-0.

Larsen-Freeman, D. (2001). Teaching grammar. Teaching English as a second or foreign language, 3, 251-266.

Makarim, Nadiem A. (2020). Surat Edaran Menteri Pendidikan dan Kebudayaan Republik Indonesia tentang pembelajaran secara Daring dan Bekerja dari Rumah dalam Rangka Pencegahan Penyebaran Corona Virus Disease (COVID-19)

Osmani. Shkurte Luma, et.al. (2016). International on Sustainable Development (Book of Proceeding). www.icsd.eu

Pumjarean, W., Muangnakin, P., \& Tuntinakhongul, A. (2017). The Development of blended e-learning using Moodle's LMS for EFL Grammatical and writing instruction for first-year students in the English major. Journal of Education and Social Sciences, 7(1), 81-89.

Rymanova, I., Baryshnikov, N., \& Grishaeva, A. (2015). E-course based on the LMS Moodle for English language teaching: Development and implementation of results. Procedia-Social and Behavioral Sciences, 206, 236-240.

Seemab Khan, M., Ali, F., Mustafa, G., \& Farooqi, S. U. H. (2018). Effectiveness of an educational software system (Desire2Learn) in teaching English grammar. Arab World English Journal (AWEJ) Special Issue on CALL, (4).

Silverman, David \& Marvasti Amir (2008). Doing Qualitative Research (A Comprehensive Guide). London: Sage Publications

Widodo, H. (2006). Approaches and procedures for teaching grammar. English teaching, 5(1), 121. 